\title{
$\begin{array}{llllllll}\text { A } & \mathrm{R} & \mathrm{T} & \mathrm{I} & \mathrm{C} & \mathrm{L} & \mathrm{E} & \mathrm{S}\end{array}$
}

\section{TRIANGULATING ENVIRONMENTAL PERFORMANCE: WHAT DO CORPORATE SOCIAL RESPONSIBILITY RATINGS REALLY CAPTURE?}

\author{
MAGALI A. DELMAS \\ University of California, Los Angeles \\ DROR ETZION \\ McGill University \\ NICHOLAS NAIRN-BIRCH \\ University of California, Los Angeles
}

\begin{abstract}
The emergence of socially responsible investing has led to the development of a large number of methodologies for rating corporate social responsibility and to a growing body of research exploring the link between environmental and financial performance. Increased availability of information potentially generates an abundance of riches upon which to base investment decisions, but it also raises issues of commensurability, information overload, and confusion. Using a unique data set combining environmental ratings from three leading purveyors, we identify the principal components of corporate environmental performance. We find that two distinct factors-the environmental processes and practices implemented by firms, and the environmental outcomes they generate-explain $80 \%$ of the variance of the data. We also find corporate financial performance to be associated to process but not to outcome measures.
\end{abstract}

Socially responsible investing (SRI) is an investment philosophy that uses screens based on environmental and social preferences to select or avoid investing in certain companies (Renneboog, Ter Horst, \& Zhang, 2008). SRI has grown consistently in recent years, and currently more than $11 \%$ (\$3.31 trillion) of assets under professional management in the United States are invested with social responsibility in mind (Social Investment Forum, 2012). As it gains in stature and legitimacy, SRI is in a unique position to orient corporations toward corporate sustainability because firms that pass these screens can attract capital more easily (Ambec \& Lanoie, 2008; Chatterji \& Levine, 2006; Delmas \& Blass, 2010; O’Rourke, 2003; Siegel, 2009). Consequently, as SRI becomes more prevalent, firms may strive to improve their environmental and social performance to be included in such indices (Chatterji \& Toffel, 2010).
Unsurprisingly perhaps, as SRI has grown it has led to a proliferation of ratings to assess corporate social responsibility and environmental performance. Unlike financial performance indicators, which over time have become well defined and standardized, to date there has been no convergence upon universally accepted environmental and social performance indicators. In fact, more than 50 distinct rating methodologies for assessing environmental and social performance have been developed, more than a third of them since 2005 (Sadowski, Whitaker, \& Buckingham, 2010). In large part, these ratings are produced by small, specialized organizations aiming to provide nonfinancial performance indicators to supplement more traditional financial metrics. Yet, with an increasingly large number of ratings systems available, it becomes less likely that each new methodology will provide unique or complementary 
information. Ultimately, the emergence of a wide variety of rating systems, coupled with the disparity and opacity of the methodologies employed, calls into question the reliability and comparability of ratings, as well as their utility to investors, managers, and researchers alike (Porter \& Kramer, 2002). Because of the multiplicity of metrics, there is a risk that investors will lose confidence in SRI screens as a basis for investment decisions (Chatterji \& Levine, 2006). Furthermore, corporate managers might be confused on how to prioritize their investments in environmental and social improvements to bolster their firms' reputation with investors (Delmas \& Blass, 2010).

The proliferation of disparate rating methodologies is attributable not only to the growth of SRI but also to the inherent complexity of "environmental and social performance," an essentially artificial construct that can be interpreted and evaluated in many ways. Emphasis can be placed, for example, on greenhouse gas emissions, which contribute directly to climate change, an issue that many consider to be the most dire of environmental concerns. But climate change is only one of many ways in which corporate activity touches the natural environment. In fact, environmental concerns are apparent in many other domains, including issues as diverse as water usage, biodiversity loss, and the release of toxic materials. Likewise, corporate philanthropy can be one element of social performance along with many others such as diversity in the workplace and employee benefits. How data are selected and aggregated in a single score inevitably prioritizes some issues over others, whether purposefully or not. Yet the proprietary nature of rating methodologies often precludes full transparency; as a consequence, little is known about the specifics behind each rating scheme (Chatterji \& Levine, 2006; Delmas \& Blass, 2010).

In striving to clearly define the concept of "environmental and social performance," scholars have both theoretically and empirically identified several dimensions that the construct encompasses. Yet, while there appears to be agreement that environmental and social performance is multidimensional and that the strength of the relationship between each dimension and financial performance may vary, there is little consensus in the literature on what each dimension represents and thus what corporate social responsibility ratings actually measure. Moreover, in investigating these dimensions, scholars have disproportionately relied on ratings produced by one provider-KLD Research and Analytics-rather than using multiple independent ratings to more robustly capture the essence of environmental and social performance.

In an effort to attain greater clarity on the measurement of corporate social responsibility (CSR), in this study we attempt to determine whether the information provided by leading rating organizations can be reduced to a small number of unique dimensions that capture the cardinal aspects of CSR, and whether these dimensions are associated with financial performance. Empirically, we focus our attention solely on the environmental component of sustainability ratings. We do so for two reasons. First, environmental performance is covered by a larger number of ratings schemes than social performance. Second, environmental performance is more easily quantifiable than social performance, and thus better suited for empirical analysis. Greenhouse gas emissions, water usage, and recycling rates, for example, are more amenable to numerical representation than labor practices and stakeholder engagement practices (Global Reporting Initiative, 2006).

We examine the environmental evaluations of more than 200 U.S. firms as assessed by KLD Research and Analytics, Trucost, and Sustainable Asset Management (SAM) from 2004 through 2007. These sources of performance ratings have been used in more than 100 management research articles. ${ }^{1}$ Our study is the first to explicitly triangulate data from these different independent sources. This triangulation reveals that two dimensions-environmental processes and environmental outcomes-explain roughly $80 \%$ of the variance of the data. The process dimension captures the management practices that firms put into place to improve their environmental performance. The outcome dimension captures the effects of these practices on actual environmental performance currently in place in the organization. We find that the process dimension of environmental performance is more significantly related to financial performance than the outcome dimension. These results can inform both managers and investors on the elements of social and environmental performance that are the most likely to be linked to financial performance.

\section{ENVIRONMENTAL RATINGS}

Socially responsible investing is based on the assumption that good environmental performance

\footnotetext{
${ }^{1}$ See appendix for a list of these studies.
} 
can be associated with good financial performance (Siegel, 2009). There are several rationales for this assumption. First, by reducing the amount of materials and energy used in industrial activity, corporations become both greener and leaner, reducing their production costs and thereby increasing profitability (King \& Lenox, 2001). Similarly, by reducing emissions and wastes, firms reduce both waste management costs and fines that result from noncompliance with regulations. In doing so, firms also reduce the exposure they will face if and when future regulations come into effect (Reinhardt, 1999). Furthermore, by establishing a reputation as a responsible organization, a corporation can both reduce the effect of adverse environmental mishaps on its valuation (Doh, Howton, Howton, \& Siegel, 2009; Godfrey, Merrill, \& Hansen, 2009) and also benefit from supportive and long-lasting relationships with a wide array of stakeholders, including employees, customers, suppliers, communities, and of course investors (Delmas, 2001; Delmas \& Montiel, 2009; Delmas \& Pekovic, 2013; Freeman, 1984).

Whether these theoretical predictions also hold in reality has been the subject of a great number of studies (Barnett \& Salomon, 2006; Brammer \& Millington, 2008; Dowell, Hart, \& Yeung, 2000; King \& Lenox, 2001; Marcus \& Fremeth, 2009; Ramchander, Schwebach, \& Staking, 2012; Russo \& Fouts, 1997; Sharfman \& Fernando, 2008; Waddock \& Graves, 1997). Yet despite this large body of research, much uncertainty about the significance of the relationship remains. Meta-analyses, which aggregate results from individual studies, suggest that the link between environmental and financial performance is weak (Margolis \& Walsh, 2003; Orlitzky, Schmidt, \& Rynes, 2003). Nonetheless, the financial consequences of being perceived as a socially and environmentally responsible corporation can be significant. For example, Lyon and Shimshack (in press) have shown that merely appearing in the top $20 \%$ of Newsweek's prestigious Greenest Companies list yields an immediate measurable increase in stock valuation, even though the data on which the list is based is readily available to the market before the list is announced.

These mixed results, according to some, might be partly due to misspecified models, the difficulty of measuring environmental performance, and important differences among screening methodologies (Griffin \& Mahon, 1997; McWilliams \& Siegel, 2000, 2001). Indeed, rating methodologies for environmental performance are as varied as the data on which they are based (Delmas \& Blass, 2010). However, disparate methodological approaches that can be viewed as suboptimal can also provide insight and perspective (Ilinitch, Soderstrom, \& Thomas, 1998). Akin to distinct measures of financial performance, such as Tobin's q, return on assets (ROA), and return on equity (ROE) (Chakravarthy, 1986; Venkatraman \& Ramanujam, 1986), distinct methodologies for assessing environmental performance add nuance to a complex concept. This variety gives investors and other audiences several options to evaluate performance and inform decision making. However, whereas environmental performance is a construct no less complex than financial performance, its underlying dimensions are not as clearly defined or well understood.

\section{Two Dimensions?}

Researchers have developed various models for conceptualizing the corporate environmental performance (CEP) construct, most of which identify two dimensions. Several recent studies posit a clear distinction between doing environmental "good" versus "bad." In other words, these studies suggest that positive environmental performance and negative environmental performance are not mirror images, and therefore one cannot be expressed as a linear transformation of the other. Minor and Morgan (2011), for example, claimed that by "doing good" firms aren't necessarily "avoiding harm" to the environment. Similarly, Mattingly and Berman (2006) corroborated the claim that positive and negative social actions are empirically and conceptually distinct aspects of a more general social performance construct. Strike, Gao, and Bansal (2006) also showed that responsible and irresponsible social behaviors require separate measurement and that each has a distinct correlation to financial performance.

Other researchers have identified dimensions of corporate environmental performance based on the target stakeholder group. Focusing on the financial consequences of social actions, Hillman and Keim (2001) differentiated between actions aimed at primary (e.g., employees, customers, and communities) versus secondary stakeholders (e.g., those associated with social issues not directly related to the firm) and demonstrated that only the former are associated with profitability. Researchers have also dichotomized social and environmental ratings as forward- versus backward-looking. In their assessment of the accuracy of KLD environmental ratings, 
Chatterji, Levine, and Toffel (2009) emphasized the need for ratings to capture both historical environmental performance and current managerial practices. They find that KLD ratings do not make optimal use of publicly available environmental performance data. In sum, prior research reveals that environmental performance is not a unidimensional construct, and suggests that it may be captured rather comprehensively with two dimensions-although precisely what these two dimensions represent remains unclear.

In this paper, we build upon a two-dimensional view of social and environmental ratings that distinguishes between processes and outcomes (Busch \& Hoffmann, 2011; Chen \& Delmas, 2010, 2012; Wood, 1991). Outcome-based measures take into account only environmental impacts whereas process-based measures consider internal efforts, such as commitment to environmental causes, sophistication of environmental management systems, and managerial quality in general (Chen \& Delmas, 2010). In other words, process-based measures represent the actions that firms take that in turn affect the firm's environmental performance.

Process and outcome measures differ in several ways. First, process-based measures are often intangible and more difficult to measure than environmental outcome such as toxic releases. Second, process measures indicate the efforts a company invests in attempting to mitigate its environmental impacts. Although process measures represent a potential for improvement in outcome performance, there is no guarantee that such improvements will indeed materialize (Schneider \& Meins, 2012). It is therefore unclear whether the two dimensions can or should be used independently by socially responsible investors. For example, using survey responses, Busch and Hoffmann (2011) found that their outcome-based measure-self-reported greenhouse gas emissions-had a positive relationship with financial performance, while the opposite was true for process-based measures.

\section{METHOD}

\section{Environmental Performance Ratings}

We examine environmental performance ratings produced by three different rating organizations: KLD, Trucost, and SAM. The widespread reliance on these ratings in scholarly publications is depicted in the appendix. These three rating schemes are also highly visible not only to investment man- agers and executives but also to general audiences more broadly. For example, the Newsweek Green Rankings are based in large part on data from KLD and Trucost (Lyon \& Shimshack, in press). SAM provides the data for the world's first family of sustainability indices, the Dow Jones Sustainability Indexes (Cerin \& Dobers, 2001).

\section{KLD}

KLD Research and Analytics rates the environmental and social performance of all firms listed on the Russell 3,000, representing approximately $98 \%$ of the investable U.S. equity market. The KLD database creates seven individual binary "strength" and "concern" scores, respectively, across a range of environmental performance categories, including products and services (e.g., beneficial products and services and agricultural chemicals); operations and management (e.g., pollution prevention, recycling, management systems, and substantial emissions); and climate change (e.g., clean energy and revenues from coal, oil, and derivative products). These assessments are based on publicly available information from a comprehensive set of media providers; they do not rely at all on data provided by the companies themselves. While thus ensuring greater objectivity, KLD ratings are much less granular than those found in other methodologies, capturing primarily noteworthy environmental activity, whether positive or negative, as reported by media sources. This is by far the most widely used data set in research on environmental performance (Chen \& Delmas, 2010; Etzion, 2007).

\section{Trucost}

Trucost performance indicators quantify a broad range of environmental impacts for the largest publicly traded U.S. companies, including all Standard and Poor (S\&P) 500 firms. The variables cover both direct and supply chain activities, such as emissions and waste production, water abstraction, natural resource use, and raw materials extraction. Where it is available, Trucost collects, standardizes, and validates company-reported environmental data from annual reports, corporate Web sites, and other public disclosures. Where not disclosed publicly, data are calculated from global fuel use, or imputed by conducting a detailed sector breakdown of each firm and applying a proprietary input-output (IO) economic model based on government census and survey data, industry data and 
statistics, and national economic accounts. Trucost then quantifies the various environmental impacts and damage costs associated with these extractions and emissions using methodologies developed in the environmental economics literature, which are vetted by an independent academic advisory panel.

\section{SAM}

Sustainable Asset Management (SAM) is a Swiss company specializing in sustainability investments. Its rankings focus primarily on the largest 2,500 companies (by market cap) listed in the Dow Jones Wilshire Global Total Market Index, which comprises the largest firms in developed and emerging markets. Unlike KLD, the basis of SAM's rating methodology is firm responses to sustainability surveys, performed and analyzed annually. SAM asks companies in its universe to fill in detailed Web-based questionnaires regarding various aspects related to their economic, social, and environmental performance. Response rates are roughly $20 \%$. An additional group of companies, also comprising around $20 \%$ of the SAM universe, is analyzed with publicly available information. These are firms that have participated in past surveys, or that SAM analysts believe are especially worthwhile of coverage, usually because they are large. In sum, analysis is available for around $40 \%$ of the world's largest companies.

\section{Measures}

We extract from each of the three data providers the most significant measures of environmental performance that have been used in the literature (see Table 1). Based on the KLD data, we create two variables-Total concerns and Total strengths - by separately aggregating all environmental strength and concern scores, respectively, for each firm. From Trucost we use the Total damage cost vari- able for each firm, which aggregates all direct and indirect damage variables. From SAM, we use two measures: eco-efficiency and environmental reporting. Eco-efficiency is based on comparison of resource inputs (i.e., water use in cubic meters and total energy consumption in giga-joules) to outputs (i.e., greenhouse gas emissions in metric tons of carbon dioxide equivalents and total waste generation in metric tons), but the measure puts a higher weight on the resource inputs than the outputs. Reporting evaluates the quality and degree of transparency in environmental reporting based on company disclosures and reports.

Our analysis incorporates all firms common to all three data sets, essentially encompassing the largest public U.S. firms in the years 2004 through 2007. Merging these data yields an unbalanced panel encompassing 475 firms and a total of 1,072 complete firm-year observations available for the principal component analysis (PCA) portion of our analysis. Tables 2 and 3 provide descriptive statistics and correlations.

\section{Stage 1: Principal Component Analysis}

We use PCA, a method developed to reduce the dimensionality of a data set in which there are a number of interrelated variables while retaining as much of the variation as possible (Jolliffe, 2002). PCA replaces $p$ correlated variables with $q$ uncorrelated variables (called "components") in a way that minimizes loss of information, where $p>q$. Each component is a linear combination of the measured variables:

$$
y_{j}=a_{1 j} x_{1}+a_{2 j} x_{2}+\cdots+a_{p j} x_{p},
$$

Where $\mathrm{x}_{1}, \mathrm{x}_{2} \ldots \mathrm{x}_{\mathrm{p}}$ are the standardized original measurement and the $\mathrm{a}_{\mathrm{ij}}$ ' $\mathrm{s}$ are coefficients for variable $i$ on component $j$. The coefficients reflect the relative contribution each variable makes to the

TABLE 1

Environmental Ratings Descriptions

\begin{tabular}{|c|c|c|}
\hline Ratings & Variable name & Description \\
\hline KLD & Total Concerns & $\begin{array}{l}\text { Total environmental concerns: Hazardous waste, regulatory problems, substantial emissions, } \\
\text { climate change }\end{array}$ \\
\hline Trucost & Total Damage Cost & Total environmental damage cost (mUSD) associated with firm activity \\
\hline SAM & Eco-efficiency & Energy and water usage (inputs) vs. GHG emissions and waste (outputs) \\
\hline
\end{tabular}


TABLE 2

Descriptive Statistics

\begin{tabular}{|c|c|c|c|c|c|}
\hline Variable & Obs. & Mean & Std. dev. & Min. & Max. \\
\hline Trucost Total Damage & 741 & 665.23 & $1,314.77$ & 1.21 & $13,323.73$ \\
\hline KLD Total Concerns & 741 & 0.63 & 1.09 & 0.00 & 5.00 \\
\hline SAM Reporting & 741 & 36.56 & 36.93 & 0.00 & 100.00 \\
\hline KLD Total Strengths & 741 & 0.54 & 0.90 & 0.00 & 4.00 \\
\hline PC Environmental Processes & 741 & 0.09 & 1.04 & -2.91 & 3.42 \\
\hline Growth & 741 & -2.36 & 0.99 & -16.12 & -0.32 \\
\hline Capital Intensity & 741 & -2.99 & 0.97 & -6.69 & 0.38 \\
\hline Firm Size & 741 & 9.05 & 1.25 & 6.10 & 12.53 \\
\hline
\end{tabular}

component, and are commonly rescaled to reflect the most important components. The rescaled coefficients are called component loadings and are interpreted as the correlation coefficient between variable $i$ and component $j$. Each component $y_{\mathrm{i}}$ accounts for a portion of the overall variation. The principal components are the $q$ components that account for the highest amount of variation. By construction, the components are orthogonal to each other and thus describe a unique dimension of variation. The components can therefore be interpreted by examining how the variables in each subset relate to one another and, in turn, are distinct from other subsets.

In the first part of our analysis we used PCA to identify the principal components captured by the three methodologies. Column 1 of Table 4 describes the results with a varimax rotation, which yields components orthogonal to each other. This rotation is advantageous for highlighting the distinction between components, but in instances when components are not likely to be independent, a non-orthogonal rotation may be preferable. Column 2 thus presents the results of principal component analysis with a promax rotation, which relaxes the orthogonality constraint. With the varimax rotation

TABLE 3

Correlation Matrix of Environmental Ratings

\begin{tabular}{llccccc}
\hline \multicolumn{1}{c}{ Variable } & $\mathbf{1}$ & $\mathbf{2}$ & $\mathbf{3}$ & $\mathbf{4}$ & $\mathbf{5}$ \\
\hline $\mathbf{1}$ & Trucost Total Damage & 1.00 & & & & \\
$\mathbf{2}$ & KLD Total Concerns & 0.61 & 1.00 & & & \\
$\mathbf{3}$ & SAM Eco-efficiency & 0.35 & 0.46 & 1.00 & & \\
$\mathbf{4}$ & SAM Reporting & 0.32 & 0.44 & 0.76 & 1.00 & \\
$\mathbf{5}$ & KLD Total Strengths & 0.23 & 0.38 & 0.66 & 0.58 & 1.00 \\
\hline
\end{tabular}

All coefficients are significant at the 5\% level. the two most significant components account for nearly $80 \%$ of the variance in the data, and with the promax this number rises to nearly $95 \%$, suggesting that indeed environmental performance can generally be disentangled into two primary dimensions. These results suggest that the processes that a company employs to be "good" and reduce its environmental impact constitute one dimension, whereas its actual impacts-the "harm" it generates in terms of releases to the environment and damages that these releases create-constitutes a separate dimension. We label the first dimension PC environmental processes and the second dimension $P C$ environmental outcomes. The Environmental processes component includes the variables Total strengths from KLD and Eco-efficiency and Reporting from SAM. These variables primarily represent the adoption of environmental management practices and reporting and also provide some indication of resource inputs. The Environmental outcomes component includes the Total concerns variable from KLD and the Total damage variable from Trucost, which both represent environmental outputs or outcomes.

\section{Stage 2: Financial Impact}

In the second stage of our analysis we used panel data analysis to examine the relationship between each of the two principal components and firm value. Below we describe the variables and methods.

Dependent variable. Tobin's q was used to measure firm value. Tobin's q is defined as the ratio of a firm's market value to the replacement cost of its assets, which this study approximates using the method developed in Chung and Pruitt (1994). To- 
TABLE 4

Principal Component Analysis

\begin{tabular}{|c|c|c|c|c|c|}
\hline \multirow{2}{*}{$\begin{array}{c}\text { Data } \\
\text { source }\end{array}$} & \multirow{2}{*}{$\begin{array}{l}\text { Environmental } \\
\text { performance } \\
\text { variable }\end{array}$} & \multicolumn{2}{|c|}{$\begin{array}{c}1 \\
\begin{array}{c}\text { Orthogonal rotation } \\
\text { (varimax) }\end{array} \\
\text { Component }\end{array}$} & \multicolumn{2}{|c|}{$\begin{array}{c}\begin{array}{c}2 \\
\text { Oblique rotation } \\
\text { (promax) }\end{array} \\
\text { Component }\end{array}$} \\
\hline & & 1 & 2 & 1 & 2 \\
\hline SAM & Eco-efficiency & 0.87 & 0.26 & 0.88 & 0.07 \\
\hline KLD & Total Concerns & 0.11 & 0.92 & 0.15 & 0.81 \\
\hline \multirow[t]{4}{*}{ Trucost } & Total Damage & 0.32 & 0.83 & -0.10 & 0.96 \\
\hline & Eigenvalue & 2.32 & 1.66 & 2.67 & 2.07 \\
\hline & Variance Explained & $46.34 \%$ & $33.17 \%$ & $53.41 \%$ & $41.34 \%$ \\
\hline & Cumulative Variance Explained & $46.34 \%$ & $79.50 \%$ & $53.41 \%$ & $94.75 \%$ \\
\hline
\end{tabular}

bin's q is widely used in empirical studies of the environmental-financial performance relationship (Busch \& Hoffmann, 2011; Dowell et al., 2000; King \& Lenox, 2002; Konar \& Cohen, 2001).

Independent variables. The two principal components $P C$ environmental processes and $P C$ environmental outcomes constituted our independent variables. Each principal component is a linear transformation of the original five environmental variables.

Control variables. We included several financial variables to control for firm-level heterogeneity. Firm total assets are used to account for variation in Firm size, while Leverage is approximated by the ratio of total debt to total assets. We included the variable Growth, defined as the annual change in sales divided by total sales, to control for variations in production (King \& Lenox, 2002). Capital expenditures divided by total sales was used as a measure of Capital intensity (Elsayed \& Paton, 2005; King \& Lenox, 2002). Although it was suggested as a necessary control variable (McWilliams \& Siegel, 2000), due to a prohibitively large number of missing values for Research and development expenditures in the Compustat database, this variable was not included in our analysis. To correct for skewed distributions, each of the financial control variables was transformed using the natural logarithm. Finally, year and industry dummy variables controlled for annual trends and differences across 18 sectors.

Analysis. Our model of firm financial performance is:

$$
y_{\mathrm{it}+1}=\alpha_{i}+\beta X+\mu_{\mathrm{it}}, i=1, \cdots, \mathrm{N} ; t=1, \cdots, \mathrm{T}
$$

Where $y_{\mathrm{it}+1}$ is the financial performance of firm $i$ in year $t+1, \alpha_{i}$ is the unobserved firm-level effect, and $\beta$ is the vector of estimated regression coefficients for each of the explanatory variables measured in the matrix, $X$ (Wooldridge, 2006). To account for the time it takes for environmental information to become available to the market (Chatterji et al., 2009), the observations in $X$ are lagged one year behind the dependent variables.

Coefficients were estimated based on a random effects model. A random effects model is appropriate when the number of panels (i.e., firms) greatly exceeds the time dimension, as is the case with our unbalanced sample (475 firms over four years). Randomly assigning the firm-level effect allows for estimation to be based on variation across firms. The fixed effects model, although a conservative approach, relies on variation within firms (Baltagi, 2005). We thus based our model choice on the structure of our panel data (Baltagi, 2005; Dowell et al., 2000; Elsayed \& Paton, 2005).

Table 5 contains the correlation matrix of regression variables; regression results are described in Table 6. Calculating Tobin's q requires a relatively high number of financial variables, making it susceptible to missing values. As such, the sample size for the regression analysis is reduced. We focus on models 3 and 4, which include the PC environmental processes and $P C$ environmental outcomes variables. Model 3 uses the results of the varimax rotation; model 4 uses the results of the promax rotation. Both show that PC environmental processes has a significant and positive impact on Tobin's $\mathrm{q}(p>.001)$. The estimated marginal effect 
TABLE 5

Correlation Matrix of Regression Variables

\begin{tabular}{|c|c|c|c|c|c|c|c|c|c|c|c|c|}
\hline & Variable & 1 & 2 & 3 & 4 & 5 & 6 & 7 & 8 & 9 & 10 & 11 \\
\hline 2 & KLD Total Concerns & 0.59 & 1.00 & & & & & & & & & \\
\hline 4 & SAM Reporting & 0.25 & 0.37 & 0.74 & 1.00 & & & & & & & \\
\hline 5 & KLD Total Strengths & 0.19 & 0.30 & 0.64 & 0.57 & 1.00 & & & & & & \\
\hline 6 & PC Environmental Processes & 0.05 & 0.24 & 0.87 & 0.84 & 0.84 & 1.00 & & & & & \\
\hline 9 & Growth & -0.10 & -0.10 & -0.10 & -0.16 & -0.13 & -0.13 & -0.08 & -0.05 & 1.00 & & \\
\hline 10 & Capital Intensity & 0.10 & 0.19 & 0.06 & 0.12 & -0.01 & 0.03 & 0.16 & 0.06 & 0.02 & 1.00 & \\
\hline 11 & Firm Size & 0.47 & 0.40 & 0.38 & 0.38 & 0.26 & 0.29 & 0.43 & 0.23 & -0.11 & 0.11 & 1.00 \\
\hline
\end{tabular}

All coefficients above 0.061 are significant at the $5 \%$ level.

suggests that, all else being equal, a one-standarddeviation increase in the PC environmental processes dimension is associated with a 0.116 or 0.118 increase in Tobin's q (6\% increase relative to the mean). The coefficient for $P C$ environmental

TABLE 6

Regression Analysis (Tobin's q)

\begin{tabular}{|c|c|c|c|c|}
\hline \multirow[b]{2}{*}{ Variables } & \multicolumn{4}{|c|}{ Model } \\
\hline & 1 & 2 & 3 & 4 \\
\hline PC Environmental & & & 0.116 & 0.118 \\
\hline Processes & & & $(0.005)^{* *}$ & $(0.005)^{* *}$ \\
\hline PC Environmental & & & 0.030 & 0.004 \\
\hline Outcomes & & & $(0.568)$ & $(0.936)$ \\
\hline Trucost Total & & 0.000 & & \\
\hline Damage & & $(0.408)$ & & \\
\hline KLD Total & & -0.051 & & \\
\hline Concerns & & $(0.273)$ & & \\
\hline SAM & & 0.004 & & \\
\hline Eco-efficiency & & $(0.018)^{*}$ & & \\
\hline SAM Reporting & & $\begin{array}{c}0.002 \\
(0.240)\end{array}$ & & \\
\hline $\begin{array}{l}\text { KLD Total } \\
\text { Strengths }\end{array}$ & & $\begin{array}{r}-0.030 \\
(0.518)\end{array}$ & & \\
\hline Leverage & $\begin{array}{c}-0.041 \\
(0.000)^{* *}\end{array}$ & $\begin{array}{l}-0.042 \\
(0.000)^{* *}\end{array}$ & $\begin{array}{l}-0.042 \\
(0.000)^{* *}\end{array}$ & $\begin{array}{l}-0.042 \\
(0.000)^{* *}\end{array}$ \\
\hline Growth & $\begin{array}{c}0.036 \\
(0.215)\end{array}$ & $\begin{array}{c}0.036 \\
(0.230)\end{array}$ & $\begin{array}{c}0.041 \\
(0.162)\end{array}$ & $\begin{array}{c}0.041 \\
(0.162)\end{array}$ \\
\hline Capital Intensity & $\begin{array}{c}0.100 \\
(0.026)^{*}\end{array}$ & $\begin{array}{c}0.090 \\
(0.043)^{*}\end{array}$ & $\begin{array}{c}0.088 \\
(0.050)^{*}\end{array}$ & $\begin{array}{c}0.088 \\
(0.050)^{*}\end{array}$ \\
\hline Firm Size & $\begin{array}{l}-0.132 \\
(0.000)^{* *}\end{array}$ & $\begin{array}{l}-0.174 \\
(0.000)^{* *}\end{array}$ & $\begin{array}{c}-0.168 \\
(0.000)^{* *}\end{array}$ & $\begin{array}{c}-0.168 \\
(0.000)^{* *}\end{array}$ \\
\hline Observations & 741 & 741 & 741 & 741 \\
\hline R-squared & 0.27 & 0.31 & 0.30 & 0.30 \\
\hline Number of groups & 391 & 385 & 385 & 385 \\
\hline
\end{tabular}

$p$-values in parentheses

${ }^{+}$significant at $10 \%$; ${ }^{*}$ significant at $5 \%$; ${ }^{* *}$ significant at $1 \%$ outcomes is also positive, but does not differ significantly from zero. To confirm the validity of our findings, we repeated the analyses using ROA as the dependent variable and obtained substantively identical results. As a further robustness test, we ran the same analyses with no lag structure and again found identical results.

Interestingly, when we used the individual variables that constitute the principal components (model 2), only Eco-efficiency was significant $(p>.05)$. This is likely a result of collinearity (see Table 3) between the individual variables, suggesting that model 2 is overly specified. With just two principal components-which explain nearly $80 \%$ (model 3) or nearly 95\% (model 4) of the variation in the five independent variables of model 2-results are more reliable.

\section{CONCLUSIONS}

Corporate environmental performance, like financial performance, is an elusive and contestable metric. Yet it is undoubtedly becoming an important one, as attested to by increased reporting and scrutiny, with ever-expanding amounts of data churned out by corporations, regulators, rating organizations, and academic researchers. This abundance of riches, however, may well constitute a double-edged sword. More information can yield more precise analysis and verifiability, but it can also be misleading and confusing. Our study has attempted to identify a useful balance between the competing needs for robustness and simplicity by assessing the commonality and distinctiveness of measures of environmental performance generated 
by three large rating organizations, each of which utilizes a distinct approach. As such, our study is unique both conceptually and methodologically. Conceptually, we have focused our analysis away from examination of a specific rating scheme in isolation, and instead emphasized the advantage inherent in data drawn from multiple sources. Such an approach in essence mimics that of a savvy investor with a range of information sources at her disposal. Methodologically, we have applied a novel approach to examining environmental ratings that harnesses the discriminative capacity of principal component analysis to tease apart the key dimensions captured conjointly by the three rating organizations.

Corroborating prior research, we found that environmental performance cannot be reduced to one dimension, but that two dimensions are perhaps sufficient to depict it accurately by capturing nearly $80 \%$ of the variance of the data. Whereas prior research has suggested a dichotomy of "good" versus "bad" dimensions or process versus outcome dimensions or historical versus current dimensions, our results suggest that these dimensions in fact overlap. Processes that companies put in place to do "good" and reduce future environmental impacts constitute one dimension, whereas actual current negative releases that are "bad" for the environment constitute a different dimension.

Yet the fact that there are indeed two distinct dimensions implies that process and outcome, at least as pertains to environmental impacts, are much less linked than we would perhaps expect. Companies may excel at reporting, governance, and the utilization of environmental performance systems but still emit substantial amounts of pollution. Or, more cynically, they may put in place processes for symbolic purposes but not meaningfully pursue substantial outcomes (Delmas \& Cuerel Burbano, 2011; Delmas \& Montes-Sancho, 2010). Process measures can be easily communicated by companies, and so are convenient for environmental rating purposes.

If this is indeed true, it is perhaps unsurprising to find financial performance uncorrelated with outcomes measures yet positively correlated with process measures. Markets can respond only to information available to them. These results are consistent with a study by Hawn and Ioannou (2012), who found that symbolic environmental and social governance has a high positive impact on market value. If process measures are more abundant and can be easily fed into ratings meth- odologies, they will influence market valuation. Ideally, these processes would translate into expected outcomes. However, as our analysis demonstrates, processes and outcomes are distinct dimensions. Even if one is ascertained precisely, it sheds little light on the other. But it is these actual environmental outcomes, with their tangible and material impacts on the earth, that ultimately matter. Our financial systems, it seems, have yet to embrace this fact.

For managers in corporations that are evaluated, the implications of our study present a quandary. If markets primarily reward corporations for putting in place practices related to environmental processes, rather than outcomes, managers may be tempted to put processes in place with great fanfare and invest less effort in attaining the beneficial outcomes that such processes are intended to generate. While perhaps tantalizing from a short-term perspective, such a strategy may not be wise. First, if and when negative outcomes are eventually revealed, corrective market reaction can be swift and severe (Godfrey et al., 2009). Second, as sophistication, transparency and market interest in environmental performance increase, investors are likely to become increasingly judicious in deciding which actions taken by a firm are truly substantive and which are pursued symbolically. For example, the addition of sustainability indicators into Bloomberg terminals has the capacity to dramatically increase the timeliness, specificity, and accuracy of environmental measures available to investors, making it increasingly difficult to portray token accomplishments as meaningful, both environmentally and financially.

Similar implications are salient for investment managers. By focusing primarily on processes, investors do not closely track the real environmental impacts of corporations, which may lead them to make suboptimal investment decisions. We suggest that investment managers are likely to be better served by thoroughly understanding the key advantages and disadvantages of each rating methodology available to them, and selecting from among them a set of indicators small enough to be manageable yet large enough to capture a comprehensive array of non-overlapping indicators, such as greenhouse gas emissions, water usage, and toxic releases. Failure to do so may jeopardize the confidence that investors placed in the capacity of socially responsible investing to promote meaningful progress toward greater sustainability, undermining its credibility and raison d'être. 
Finally, our research also has important implications for researchers in strategic management whose work aggregates environmental metrics. It suggests that combining the different constructs that constitute environmental performance into a single index might be misrepresentative of the dimensions of environmental performance. Although our study focused on corporate environmental performance, the concerns we raised are no less salient for the measurement of social performance. Further research should examine and incorporate these social dimensions, integrating it into future analyses of corporate social responsibility.

\section{REFERENCES}

Ambec, S., \& Lanoie, P. (2008). Does it pay to be green? A systematic overview. Academy of Management Perspectives, 22(4), 45-62.

Baltagi, B. (2005). Econometric analysis of panel data. New York: John Wiley.

Barnett, M. L., \& Salomon, R. M. (2006). Beyond dichotomy: The curvilinear relationship between social responsibility and financial performance. Strategic Management Journal, 27, 1101-1122.

Brammer, S., \& Millington, A. (2008). Does it pay to be different? An analysis of the relationship between corporate social and financial performance. Strategic Management Journal, 29(12), 1325-1343.

Busch, T., \& Hoffmann, V. H. (2011). How hot is your bottom line? Linking carbon and financial performance. Business and Society, 50(2), 233-265.

Cerin, P., \& Dobers, P. (2001). What does the performance of the Dow Jones Sustainability Group Index tell us? Eco-Management and Auditing, 8, 123-133.

Chakravarthy, B. S. (1986). Measuring strategic performance. Strategic Management Journal, 7, 437-458.

Chatterji, A., \& Levine, D. (2006). Breaking down the wall of codes: Evaluating non-financial performance measurement. California Management Review, 48(2), 29-51.

Chatterji, A. K., Levine, D. I., \& Toffel, M. W. (2009). How well do social ratings actually measure corporate social responsibility? Journal of Economics and Management Strategy, 18(1), 125-169.

Chatterji, A., \& Toffel, M. W. (2010). How firms respond to being rated. Strategic Management Journal, 31(9), 917-945.

Chen, C.-M., \& Delmas, M. (2010). Measuring corporate social performance: An efficiency perspective. Production and Operations Management, 20(6), 789804.
Chen, C.-M., \& Delmas, M. (2012). Eco- vs. productive efficiency: New approaches to effective and comparative performance analysis. Operations Research, 60(5), 1064-1079.

Chung, K., \& Pruitt, S. (1994). A simple approximation of Tobin's q. Financial Management, 23(3), 70-74.

Delmas, M. (2001). Stakeholders and competitive advantage: The case of ISO 14001. Production and Operations Management, 10(3), 343-358.

Delmas, M., \& Blass, V. D. (2010). Measuring corporate environmental performance: The trade-offs of sustainability ratings. Business Strategy and the Environment, 19, 245-260.

Delmas, M., \& Cuerel Burbano, V. (2011). The drivers of greenwashing. California Management Review, 54(1), 64-87.

Delmas, M., \& Montes-Sancho, M. (2010). Voluntary agreements to improve environmental quality: Symbolic and substantive cooperation. Strategic Management Journal, 31(6), 576-601.

Delmas, M., \& Montiel, I. (2009). Greening the supply chain: When is customer pressure effective? Journal of Economics and Management Strategy, 18(1), 171201.

Delmas, M., \& Pekovic, S. (2013). Environmental standards and labor productivity. Journal of Organizational Behavior, 34(2), 230-252.

Doh, J. P., Howton, S. D., Howton, S. W., \& Siegel, D. S. (2009). Does the market respond to endorsement of social responsibility? The role of institutions, information, and legitimacy. Journal of Management, 36, 1461-1485.

Dowell, G., Hart, S., \& Yeung, B. (2000). Do corporate global environmental standards create or destroy market value? Management Science, 46(8), 10591074.

Elsayed, K., \& Paton, D. (2005). The impact of environmental performance on firm performance: Static and dynamic panel data evidence. Structural Change and Economic Dynamics, 16(3), 395-412.

Freeman, R. E. (1984). Strategic management: A stakeholder approach. Boston: Pitman.

Global Reporting Initiative. (2006). Sustainability reporting guidelines, version 3. Amsterdam, The Netherlands: Global Reporting Initiative. Available at https://www.globalreporting.org/resourcelibrary/ G3-Sustainability-Reporting-Guidelines.pdf

Godfrey, P., Merrill, C., \& Hansen, J. (2009). The relationship between corporate social responsibility and shareholder value: An empirical test of the risk management hypothesis. Strategic Management Journal, 30, 425-445. 
Griffin, J., \& Mahon, J. (1997). The corporate social performance and corporate financial performance debate: Twenty-five years of incomparable research. Business and Society, 36(1), 5-31.

Hawn, O., \& Ioannou, I. (2012). Do actions speak louder than words? The case of corporate social responsibility (CSR). Available at http://ssrn.com/abstract= 2101775

Hillman, A., \& Keim, G. (2001). Shareholder value, stakeholder management, and social issues: What's the bottom line? Strategic Management Journal, 22(2), 125-139.

Ilinitch, A. Y., Soderstrom, N. S., \& Thomas, T. E. (1998). Measuring corporate environmental performance. Journal of Accounting and Public Policy, 17, 383408.

Jolliffe, I. T. (2002). Principal component analysis. New York: Springer-Verlag.

King, A., \& Lenox, M. (2001). Lean and green? An empirical examination of the relationship between lean production and environmental performance. Production and Operations Management, 10(3), 244257.

King, A., \& Lenox, M. (2002). Exploring the locus of profitable pollution reduction. Management Science, 48(2), 289-299.

Konar, S., \& Cohen, M. (2001). Does the market value environmental performance? Review of Economics and Statistics, 83(2), 281-289.

Lyon, T. P., \& Shimshack, J. P. (in press). Environmental disclosure: Evidence from Newsweek's Green Companies Rankings. Business and Society.

Marcus, A. A., \& Fremeth, A. R. (2009). Green management matters regardless. Academy of Management Perspectives, 23(3), 17-26.

Margolis, J. D., \& Walsh, J. P. (2003). Misery loves companies: Rethinking social initiatives by business. Administrative Science Quarterly, 48(2), 268-305.

Mattingly, J., \& Berman, S. (2006). Measurement of corporate social action: Discovering taxonomy in the Kinder Lydenburg Domini ratings data. Business and Society, 45(1), 20-46.

McWilliams, A., \& Siegel, D. (2000). Corporate social responsibility: Correlation or misspecification? Strategic Management Journal, 21, 603-609.

McWilliams, A., \& Siegel, D. (2001). Corporate social responsibility: A theory of the firm perspective. Academy of Management Review, 26(1), 117-127.

Minor, D., \& Morgan, J. (2011). CSR as reputation insurance: Primum non nocere. California Management Review, 53(3), 40-59.

Orlitzky, M., Schmidt, F. L., \& Rynes, S. L. (2003). Cor- porate social and financial performance: A metaanalysis. Organization Studies, 24(3), 403-441.

O'Rourke, A. (2003). The message and methods of ethical investment. Journal of Cleaner Production, 11(6), 683-693.

Porter, M. E., \& Kramer, M. R. (2002). The competitive advantage of corporate philanthropy. Harvard Business Review, 80, 56-68.

Ramchander, S., Schwebach, R. G., \& Staking, K. (2012). The informational relevance of corporate social responsibility: Evidence from DS400 index reconstitutions. Strategic Management Journal, 33(3), 303314.

Reinhardt, F. (1999). Market failure and the environmental policies of firms: Economic rationales for "beyond compliance" behavior. Journal of Industrial Ecology, 3, 9-21.

Renneboog, L., Ter Horst, J., \& Zhang, C. (2008). The price of ethics and stakeholder governance: The performance of socially responsible mutual funds. Journal of Corporate Finance, 14(3), 302-322.

Russo, M. V., \& Fouts, P. A. (1997). A resource-based perspective on corporate environmental performance and profitability. Academy of Management Journal, 40(3), 534-559.

Sadowski, M., Whitaker, K., \& Buckingham, F. (2010). Rate the raters: Phase one. London: SustainAbility.

Schneider, A., \& Meins, E. (2012). Two dimensions of corporate sustainability assessment: Towards a comprehensive framework. Business Strategy and the Environment, 21, 211-222.

Sharfman, M. P., \& Fernando, C. S. (2008). Environmental risk management and the cost of capital. Strategic Management Journal, 29, 569-592.

Siegel, D. S. (2009). Green management matters only if it yields more green: An economic/strategic perspective. Academy of Management Perspectives, 23(3), 5-16.

Social Investment Forum. (2012). 2012 report on socially responsible investing trends in the United States. Washington, DC: Social Investment FORUM Foundation.

Strike, V., Gao, J., \& Bansal, P. (2006). Being good while being bad: Social responsibility and the international diversification of US firms. Journal of Business Studies, 37(6), 850-862.

Venkatraman, N., \& Ramanujam, V. (1986). Measurement of business performance in strategy research: A comparison of approaches. Academy of Management Review, 11(4), 801-814.

Waddock, S. A., \& Graves, S. B. (1997). The corporate social performance-financial performance link. Strategic Management Journal, 18(4), 303-319. 
Wood, D. J. (1991). Corporate social performance revisited. Academy of Management Review, 16, 691-718.
Wooldridge, J. M. (2006). Introductory econometrics: A modern approach. Cincinnati, OH: South-Western.

\section{APPENDIX}

Environmental Performance Ratings Literature

\begin{tabular}{|c|c|c|c|c|}
\hline Publication & $\operatorname{Article(s)}$ & KLD & SAM & Trucost \\
\hline $\begin{array}{l}\text { Strategic } \\
\text { Management } \\
\text { Journal }\end{array}$ & $\begin{array}{l}\text { Chatterji and Toffel (2010); Choi and Wang (2009); Godfrey, Merrill, and Hansen } \\
\text { (2008); Hillman and Keim (2001); Hull and Rothenberg (2008); Kacperczyk (2009); } \\
\text { Muller and Kraussl (2011); Sharfman and Fernando (2008); Waddock and Graves } \\
\text { (1997b); Walls, Berrone, and Phan (2012) }\end{array}$ & 10 & 0 & 0 \\
\hline $\begin{array}{l}\text { Academy of } \\
\text { Management } \\
\text { Journal/Review }\end{array}$ & $\begin{array}{l}\text { Agle et al. (1999); Berman et al. (1999); Brown and Perry (1994); Graves and Waddock } \\
\text { (1994); Johnson and Greening (1999); Marquis et al. (2007); Rhee and Valdez (2009); } \\
\text { Slater and Dixon-Fowler (2010); Thomas and Simerly (1995); Turban and Greening } \\
\text { (1996); Wong et al. (2011) }\end{array}$ & 11 & 0 & 0 \\
\hline $\begin{array}{l}\text { Journal of } \\
\quad \text { Management }\end{array}$ & $\begin{array}{l}\text { Chiu and Sharfman (2011); de Villiers, Naiker, and van Staden (2011); Deckop et al. } \\
\text { (2006); Doh, Howton, Howton, and Siegel (2010); Neubaum and Zahra (2006); Ruf et } \\
\text { al. (1998); Wang and Choi (2010) }\end{array}$ & 7 & 0 & 0 \\
\hline $\begin{array}{l}\text { Intl. Journal of } \\
\text { Management }\end{array}$ & Kennelly and Lewis (2002); Simerly (2003) & 2 & & \\
\hline $\begin{array}{l}\text { Business \& } \\
\text { Society }\end{array}$ & $\begin{array}{l}\text { Backhaus et al. (2002); Dawkins (2002); Garcia-Castro, Arino, and Canela (2011); } \\
\text { Godfrey, Hatch, and Hansen (2010); Griffin and Mahon (1997); Luce et al. (2001); } \\
\text { Mattingly and Berman (2006); Moura-Leite, Padgett, and Galan (2011); Post, Rahman, } \\
\text { and Rubow (2011); Rehbein et al. (2004); Shropshire and Hillman (2007); Waddock } \\
\text { and Graves (1997a); Walls, Phan, and Berrone (2011); Williams and Crawford (2011) }\end{array}$ & 14 & 0 & 0 \\
\hline $\begin{array}{l}\text { Journal of } \\
\text { Business } \\
\text { Ethics }\end{array}$ & $\begin{array}{l}\text { Albinger and Freeman (2000); Banea and Rubin (2010); Bartkus and Glassman (2008); } \\
\text { Bear, Rahman, and Post (2010); Bingham, Dyer, Jr., Smith, and Adams (2011); Bird et } \\
\text { al. (2007); Bouquet and Deutsch (2008); Briscoe and Safford (2008); Cai, Jo and Pan } \\
\text { (in press); Cai, Jo and Pan (2011); Chen et al. (2008); Chen and Delmas (2010); Cho et } \\
\text { al. (2006); Dawkins and Fraas (2011a); Dawkins and Fraas (2011b); Garcia-Castro, } \\
\text { Arino, and Canela (2010); Harjoto and Jo (2011); Igalens and Gond (2005); Jackson } \\
\text { and Apostolahou (2009); Jo and Harjoto (2011); Liston-Heyes and Ceton (2008); } \\
\text { Makni, Francoeur, and Bellavance (2009); Manner (2010); McGuire et al. (2003); } \\
\text { Minor and Morgan (2011); Schreck (2011); Padgett and Galan (2010); Ruf et al. } \\
\text { (2001); Slater and Dixon-Fowler (2009); Van der Laan et al. (2008); Wagner (2010) }\end{array}$ & 28 & 2 & 1 \\
\hline Other & $\begin{array}{l}\text { Amato and Amato (2011), Business Strategy and the Environment; Atriach, Lee, and } \\
\text { Belson (2010), Accounting and Finance; Cambell and Sherman (2010), Journal of } \\
\text { Business and Economics Research; Chang and Kuo (2008), Sustainable Development; } \\
\text { Chatterji, Levine, and Toffel (2009), Journal of Economics \& Management Strategy; } \\
\text { Chen and Delmas (2010), Production and Operations Management; Cho and Patten } \\
\text { (2007), Accounting, Organizations and Society; Cho, Roberts, and Patten (2010), } \\
\text { Accounting, Organizations and Society; Dahlmann and Brammer (2011), } \\
\text { Organization Studies; de Villiers and van Staden (2011), Journal of Accounting and } \\
\text { Public Policy; Delmas and Blass (2010), Business Strategy \& the Environment; Etzion } \\
\text { (2009), Academy of Management Proceedings; Fisher-Vaden and Thornburn (2011), } \\
\text { Journal of Environmental Economics \& Management; Henriques and Sadorsky (2010), } \\
\text { Energy Economics; Jira and Toffel (2013), Manufacturing and Service Operations } \\
\text { Management; Kane, Velury, and Ruf (2005), Journal of Business Finance and } \\
\text { Accounting; Kempf and Osthoff (2007), European Financial Management; Landier, } \\
\text { Nair, and Wulf (2009), Review of Financial Studies; Meric, Watson, and Meric } \\
\text { (2012), International Research Journal of Finance and Economics; Neiling and Webb } \\
\text { (2009), Review Quantitative Financial Accounting; Slater and Dixon-Fowler (2010), } \\
\text { Academy of Management Learning and Education; Strike, Gao, and Bansal (2006), } \\
\text { Journal of International Business Studies; Waldman, Siegel, and Javidan (2006), } \\
\text { Journal of Management Studies; Webb (2004), Journal of Management and } \\
\text { Governance; Ziegler and Schoder (2010), Ecological Economics. }\end{array}$ & 16 & 5 & 5 \\
\hline Totals & 100 & 89 & 6 & 5 \\
\hline
\end{tabular}


Magali A. Delmas (delmas@ucla.edu) is a Professor of Management at the UCLA Institute of the Environment and Sustainability and the Anderson School of Management. She is the director of the UCLA Center for Corporate Environmental Performance.

Dror Etzion (dror.etzion@mcgill.ca) is an Assistant Professor of Strategy and Organization at the Desautels Fac- ulty of Management at McGill University and an Associate Member of the McGill School of the Environment.

Nicholas Nairn-Birch (nicksbirch@ioes.ucla.edu) recently earned his doctorate from UCLA's interdisciplinary Environmental Science and Engineering program at the Institute of the Environment and Sustainability. His research focuses on business strategy, environmental policy, and the natural environment. 